\title{
Progress Report on Nitric-Phosphoric Acid Oxidation (U)
}

by

R. A. Pierce

Westinghouse Savannah River Company

Savannah River Site

Aiken, South Carolina 29808

DOE Contract No. DE-AC09-89SR18035

This paper was prepared in connection with work done under the above contract number with the U.S.

Department of Energy. By acceptance of this paper, the publisher and/or recipient acknowledges the U.S. Government's right to retain a nonexclusive, royalty-free license in and to any copyright covering this paper, along with the right to reproduce and to authorize others to reproduce all or part of the copyrighted paper. 


\section{UNCLASSIFIED}

DOES NOT CONTAIN

UNCLASSIFIED CONTAOLLEO

AOC:

ROC \&

Articie:

Oricia:<smiles>C1CCCCC1</smiles>

Dare:

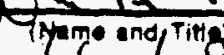

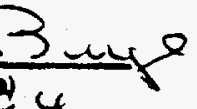

PROGRESS REPORT ON NITRIC-PHOSPHORIC ACID OXIDATION (U)

R. A. Pierce

Westinghouse Savannah River Company Savannah River Site

Aiken, SC 29808 


\section{DISCLAIMER}

This report was prepared as an account of work sponsored by an agency of the United States Government. Neither the United States Government nor any agency thereof, nor any of their employees, makes any warranty, express or implied, or assumes any legal liability or responsibility for the accuracy, completeness, or usefulness of any information, apparatus, product, or process disclosed, or represents that its use would not infringe privately owned rights. Reference herein to any specific commercial product, process, or service by trade name, trademark, manufacturer, or otherwise does not necessarily constitute or imply its endorsement, recommendation, or favoring by the United States Government or any agency thereof. The views and opinions of authors expressed herein do not necessarily state or reflect those of the United States Government or any agency thereof.

This report has been reproduced directly from the best available copy.

Available to DOE and DOE contractors from the Office of Scientific and Technical Information, P.O. Box 62, Oak Ridge, TN 37831; prices available from (615) 576-8401.

Available to the public from the National Technical Information Service, U.S. Department of Commerce, 5285 Port Royal Road, Springfield, VA 22161. 


\section{DISCLAIMER}

Portions of this document may be illegible in electronic image products. Images are produced from the best available original document. 


\section{CONTENTS}

INTRODUCTION $\ldots \ldots \ldots \ldots \ldots \ldots \ldots \ldots \ldots \ldots \ldots \ldots, 1$

TECHNOLOGY DESCRIPTION $\ldots \ldots \ldots \ldots \ldots \ldots \ldots \ldots, 1$

Oxidation Chemistry ............................ 1

Other Process Chemistry $\ldots \ldots \ldots \ldots \ldots \ldots \ldots \ldots \ldots \ldots$

RESULTS AND DISCUSSION $\ldots \ldots \ldots \ldots \ldots \ldots \ldots \ldots \ldots, 3$

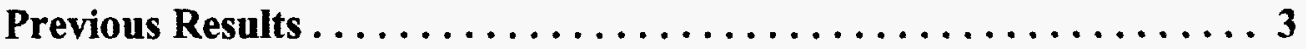

Recent Findings $\ldots \ldots \ldots \ldots \ldots \ldots \ldots \ldots \ldots \ldots \ldots \ldots, 4$

Experimental Setup ...................... 4

Oxidation of Different Compounds ................... 4

Parametric Studies with Water-Soluble Oil . . . . . . . . . . . . . 5

Oxidation of Plastics . . . . . . . . . . . . . . . . . . . . 6

Nitric Acid Recovery $\ldots \ldots \ldots \ldots \ldots \ldots \ldots \ldots \ldots \ldots$

Decontamination Effects . . . . . . . . . . . . . . . . . . . . . . 9

Materials of Construction ..................... 10

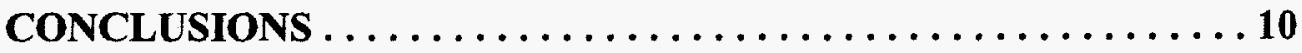

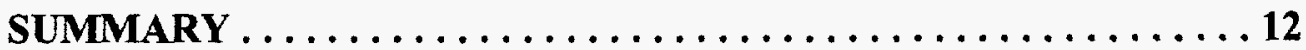

REFERENCES $\ldots \ldots \ldots \ldots \ldots \ldots \ldots \ldots \ldots \ldots \ldots \ldots \ldots \ldots \ldots$

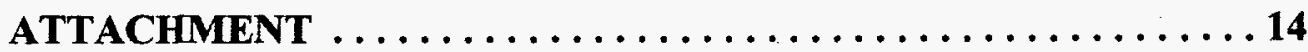




\section{INTRODUCTION}

The purpose of this program has been to demonstrate a nitric-phosphoric acid destruction technology which can treat a heterogeneous waste stream. This technology is being developed to convert hazardous liquid and solid organics to inorganic gases and salts while simultaneously performing a surface decontamination of the noncombustible items. Pu- 238 waste is an issue because it must be shipped to WIPP. However, the presence of organics and $\mathrm{Pu}-238$ exceeds packaging requirements because of concerns of hydrogen generation. If the TRU can be separated from the organics, the allowable heat load of a container increases a factor of 25 . More importantly, since the current shipping package is limited by volume and not heat loading, destroying the organic compounds and decontaminating noncombustible can potentially create a three-order magnitude decrease in the number of shipments that must be made to WIPP.

The process envisioned will be configured to handle 1 million pounds (as of 12/91) of a wide range of solid TRU-contaminated waste of which 600,000 pounds is combustible. The process will oxidize the combustibles (a mixture of $14 \%$ cellulose, $3 \%$ rubber, $64 \%$ plastics, $9 \%$ absorbed oil, $4 \%$ resins and sludges, and $6 \%$ miscellaneous organics) without requiring separation from the 400,000 pounds of noncombustibles. The system is being developed to operate below $200^{\circ} \mathrm{C}$ at moderate pressures $(0-15 \mathrm{psig})$. This report primarily discusses results obtained over the past $31 / 2$ months and their impact on the feasibility of a pilot-scale system.

\section{TECHNOLOGY DESCRIPTION}

The technology being developed is unique to SRTC and is the subject of WSRC invention disclosures. The process identified by SRTC is a wet-chemical process for completely oxidizing organic materials at moderate temperatures and pressures using common inorganic acids, nitric and phosphoric. It differs from other comparable technologies in that it does not require the use of hazardous materials or extreme processing conditions to decompose the waste.

\section{Oxidation Chemistry ${ }^{3}$}

The process uses dilute nitric acid in a concentrated phosphoric acid media as the main oxidant for the organic compounds. Phosphoric acid allows oxidation at temperatures up to $200^{\circ} \mathrm{C}$ and is relatively non-corrosive on 304-L stainless steel, especially at room temperature. Liquid phase oxidation process shouldn't produce any ash, making the system more environmentally contained. A simple process that uses oxygen from air or another readily available cheap oxidant as the net oxidizer would be relatively inexpensive per unit of waste consumed.

Many organic materials have been completely oxidized to $\mathrm{CO}_{2}, \mathrm{CO}$, and inorganic acids in a $0.1 \mathrm{M} \mathrm{HNO}_{3} / 14.8 \mathrm{M} \mathrm{H}_{3} \mathrm{PO}_{4}$ solution (see Attachment 1). Addition of $0.001 \mathrm{M} \mathrm{Pd}^{+2}$ reduces the $\mathrm{CO}$ to near $1 \%$ of the released carbon gases. To accomplish complete oxidation the solution temperature must be maintained above $130-150^{\circ} \mathrm{C}$. The oxidation is usually complete in a few hours for soluble organic materials. The oxidation rate for non-aliphatic organic solids is moderately fast and surface area dependent. 
Direct oxidation of most organic compounds by nitric acid, is energetically favorable but very slow due to its inability to break the carbon-hydrogen bond ${ }^{1,2}$. The following heats of reaction, $\Delta \mathrm{H}$, values are in $\mathrm{kcal} / \mathrm{mole}^{1,2,3}$.

$$
\begin{array}{ll}
\mathrm{RCH}_{3}+\mathrm{HNO}_{3}-\mathrm{RCH}_{2} \mathrm{OH}+\mathrm{HNO}_{2} & \Delta \mathrm{H} \cong-25 \\
\mathrm{RCH}_{3}+\mathrm{HNO}_{3}-\mathrm{RCH}_{2}+\mathrm{H}_{2} \mathrm{O}+\mathrm{NO}_{2} \cdot & \Delta \mathrm{H} \cong 35 \\
\mathrm{RCH}_{3}+\mathrm{HNO}_{2}-\mathrm{RCH}_{2}+\mathrm{H}_{2} \mathrm{O}+\mathrm{NO} \cdot & \Delta \mathrm{H} \cong 28
\end{array}
$$

$\mathrm{R}$ denotes an organic group not affecting the $\Delta \mathrm{H}$ for the shown reaction. The oxidation of organic compounds is usually initiated by the production of organic radicals generated by dissolved $\mathrm{NO}_{2} \cdot$ and $\mathrm{NO} \cdot$ in solution $\left(\mathrm{NO}_{2}\right.$ and $\mathrm{NO}$ are radicals and will be noted as such). For many types of organic compounds the attack by $\mathrm{NO}_{i}^{*}$ can be first order.

$$
\begin{aligned}
& \mathrm{CH}_{3}(\mathrm{OH}) \mathrm{CH}_{2}+\mathrm{NO}_{2}^{\bullet}-->\mathrm{CH}_{3}(\mathrm{OH}) \mathrm{CH} \bullet+\mathrm{HNO}_{2} \quad \Delta \mathrm{H} \equiv 0 \\
& \mathrm{CH}_{3} \mathrm{CHO}+\mathrm{NO}_{2} \cdot-->\mathrm{CH}_{3}(\mathrm{O}) \mathrm{C} \bullet+\mathrm{HNO}_{2} \quad \Delta \mathrm{H}=-7
\end{aligned}
$$

For aliphatic compounds higher concentrations of $\mathrm{NO}_{2}^{*}$ and $\mathrm{NO}^{*}$ are needed to obtain comparable oxidation rates.

$$
\begin{array}{ll}
\mathrm{RCH}_{3}+\mathrm{H}_{2} \mathrm{O}+3 \mathrm{NO}_{2} \cdot-->\mathrm{RCH}_{2}+2 \mathrm{HNO}_{2}+\mathrm{HNO}_{3} & \Delta \mathrm{H} \cong-15 \\
\mathrm{RCH}_{3}+\mathrm{H}_{2} \mathrm{O}+2 \mathrm{NO}_{2}+\mathrm{NO} \bullet-->\mathrm{RCH}_{2}+3 \mathrm{HNO}_{2} & \Delta \mathrm{H} \cong-8
\end{array}
$$

A typical aliphatic carbon-hydrogen bond strength of $99 \mathrm{kcal} / \mathrm{mole}$ was used in the calculations ${ }^{2}$. The organic radicals are then oxidized by nitric and nitrous acids or nitrated by $\mathrm{NO}_{2}$ :

$$
\begin{array}{lr}
\mathrm{RCH}_{2}^{*}+\mathrm{HNO}_{3}-\mathrm{CRCH}_{2} \mathrm{OH}+\mathrm{NO}_{2}^{*} & \Delta \mathrm{H} \cong-35 \\
\mathrm{RCH}_{2}^{*+} \mathrm{HNO}_{2}-->\mathrm{RCH}_{2} \mathrm{OH}+\mathrm{NO}^{\bullet} & \Delta \mathrm{H} \cong-42 \\
\mathrm{RCH}_{2}^{*}+\mathrm{NO}_{2}^{*-->} \mathrm{RCH}_{2} \mathrm{NO}_{2} & \Delta \mathrm{H} \cong-52
\end{array}
$$

Hydrogen-carbon bonds on carbon atoms which are also bonded to oxygen are weakened, allowing much quicker hydrogen abstraction and further oxidation. As the organic molecules gain more oxygen atoms the organic molecules become increasingly soluble in the nitricphosphoric acid solution. Once in solution the molecules are quickly oxidized to $\mathrm{CO}_{2}, \mathrm{CO}$, and water. If the original organic compound contains chlorine then $\mathrm{HCl}$ (hydrochloric acid) will also be formed.

\section{Other Process Chemistry}

In addition to dissolution of plastics, hot concentrated phosphoric acid has been shown to dissolve plutonium oxide more efficiently than $0.05 \mathrm{M} \mathrm{HF}$ in $\mathrm{HNO}_{3}$ (the solution often used at SRS for dissolution of $\mathrm{PuO}_{2}$ ). ${ }^{4}$ This means that the dissolution liquid should be very effective at decontaminating the non-combustible solids fed to it. As a result, the process will be suitable for all of the waste types present in the TRU waste containers. 
Acid recycle will also be another key part of the process. As the reaction progresses, NO and $\mathrm{NO}_{2}$ are released from solution and nitric acid is depleted. As a result, the $\mathrm{NO}$ and $\mathrm{NO}_{2}$ need to be recovered as nitric acid in order to maintain the initiation of reactions. At the same time, $\mathrm{HCl}$ gas from the oxidation of PVC must be allowed to pass through to be recovered in a subsequent step. Several different approaches are being considered with the goal being to simplify the process as much as possible. Acid recovery units for converting NOx to nitric acid are a commercially available technology.

The presence of TRU components, fission products, stainless steel, and lead will lead to a number of metal ions in the oxidation solution. Of particular concern is the potential for a build-up of materials to form a critical mass. Metals can be recovered by precipitation as either as phosphates or oxalatophosphates. The precipitates can then be separated using a centrifuge. ${ }^{5}$ These solids will be rinsed, dried, and shipped to WIPP.

\section{RESULTS AND DISCUSSION}

\section{Previous Results}

Early experiments demonstrated the application of nitric-phophoric oxidation for various organic materials, and the importance of adding trace $\mathrm{Pd}$ catalyst to reduce $\mathrm{CO}$ generation (Table 1 ).

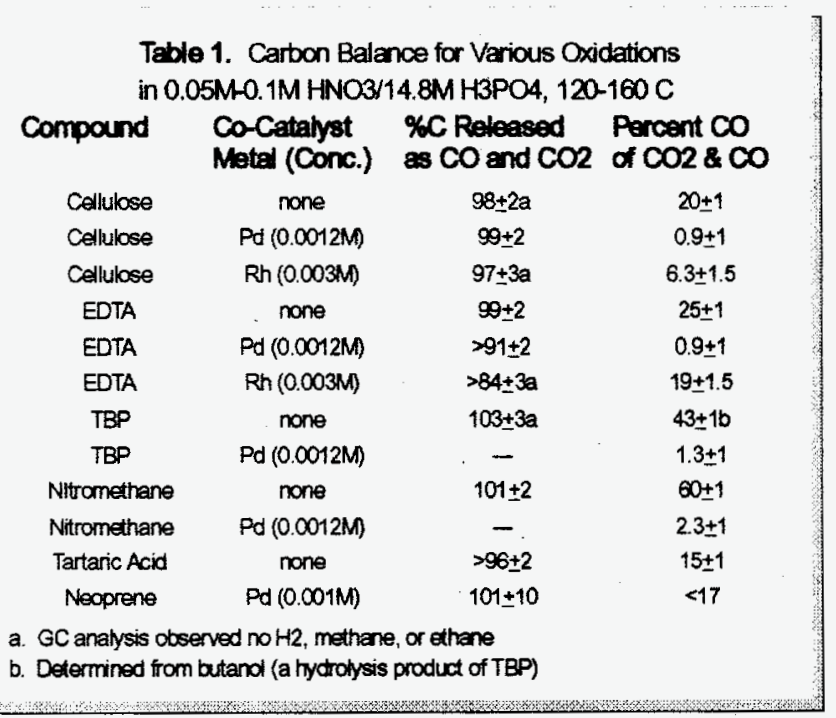

High density polyethylene has been, within experimental error, quantitatively oxidized to $\mathrm{CO}_{2}$ and $\mathrm{CO}$ under typical microwave digestion conditions in dilute nitric acid (Table 2). ${ }^{7}$ Recent data, to be discussed later, sheds additional light on the likely role of microwaves in organics oxidation. Addition of $0.001 \mathrm{M} \mathrm{Pd}$ to solution reduces $\mathrm{CO}$ production by a factor of three; higher concentrations will probably reduce $\mathrm{CO}$ even further.

A separate set of tests were performed to obtain corrosion rates for 304-L stainless steel in solutions expected to be typical following oxidation. The tests were run at room temperature since solutions will be cooled before further operations. $\mathrm{HCl}$ was included as a parameter since much of the TRU organic waste contains chloride (PVC and neoprene). The results of the study are given in Table $3 .^{7}$ Solutions of expected nitric acid concentrations in phosphoric acid produced non-corrosive mixtures. The combination of $\mathrm{HCl}$ and $\mathrm{HNO}_{3}$ is very corrosive. One of these two compounds would have to be eliminated prior to processing. Nitric acid can be destroyed with oxalic acid, and $\mathrm{HCl}$ can be boiled of with air sparging at temperatures above $150^{\circ} \mathrm{C}$. $\mathrm{Up}$ to $1.0 \mathrm{M} \mathrm{HCl}$ in phosphoric acid is in the good range $(<20$ mils/yr). 
Table 2. Carbon Balance for Oxidation of HDPE Using Microwave Digestion at $100 \mathrm{~W}$

\begin{tabular}{|c|c|c|c|c|}
\hline $\begin{array}{c}\text { Oxidizing } \\
\text { Solution }\end{array}$ & $\begin{array}{l}\text { Digestion } \\
\text { Time (min) }\end{array}$ & $\begin{array}{l}\text { T Carbon } \\
\text { Roleased to } \\
\text { Gas Phase }\end{array}$ & $\begin{array}{l}\text { Carb } \\
\text { Com } \\
\text { xco }\end{array}$ & $\begin{array}{l}\text { Gas } \\
\text { sition } \\
\times \mathrm{CO}_{2}\end{array}$ \\
\hline $15.9 \mathrm{MHNO3}$ & 30 & $50.0 \pm 2$ & 21 & 79 \\
\hline $15.9 \mathrm{M} \mathrm{HNO3}$ & 40 & $81.5 \pm 2$ & 24 & 79 \\
\hline $\begin{array}{l}1.05 \mathrm{M} \mathrm{HNO} 3 / \\
+3.8 \mathrm{M} \mathrm{H} 3 \mathrm{PO} 4\end{array}$ & 40 & $74 \pm 2$ & 18 & 82 \\
\hline $\begin{array}{l}0.55 \mathrm{M} \text { HNO3/ } \\
143 \mathrm{M} \mathrm{H} 3 \mathrm{PO} 4 \\
\end{array}$ & 55 & $84 \pm 2$ & 14 & 86 \\
\hline $\begin{array}{l}0.001 \mathrm{MPd}(11) / \\
1.00 \mathrm{HNO} / \\
13.9 \mathrm{M} \mathrm{HPO}^{\prime}\end{array}$ & 50 & $98 \pm 2$ & 6 & 94 \\
\hline
\end{tabular}

Tablo 3. 304-L Corrosion in HCVHNO 3/H3PO4 at $20 \mathrm{C}$

\begin{tabular}{|c|c|c|c|}
\hline $\begin{array}{c}\mathrm{HCl} \\
(\mathrm{M})\end{array}$ & $\begin{array}{c}\text { HNO3 } \\
(\mathrm{M})\end{array}$ & $\begin{array}{c}\text { H3PO4 } \\
(\mathrm{M})\end{array}$ & $\begin{array}{c}\text { Corrosion } \\
\text { Rato } \\
\text { (mils/yr) }\end{array}$ \\
\hline 0.12 & 0 & 0 & 3.1 \\
\hline 1.0 & 0 & 0 & $10.0 \pm 1.2$ \\
\hline 0 & 0.1 & 14.8 & $<0.36$ \\
\hline 1.0 & 0.1 & 13.5 & 224 \\
\hline 1.0 & 0 & 13.6 & 16 \\
\hline
\end{tabular}

\section{Recent Discoveries}

\section{Experimental Setup:}

All oxidation experiments were conducted using some variation of the test set-up in Figure 1, with the exception of early microwave tests. Pressure was measured using a Marshalltown Manufacturing compound gauge which measures from $30 " \mathrm{Hg}-30$ psig. The system temperature was monitored using a laboratory thermometer in some cases and a Luxtron Model 750 Fluoroptic temperature probe in others. Ascarite- $\mathrm{II}^{\mathbb{B}}$ (Thomas Scientific) absorbs $\mathrm{CO}_{2}$ and then is weighed to determine how much carbon dioxide has been released from the reaction; weights are taken using a calibrated Mettler AE200 balance which is accurate to $0.0001 \mathrm{~g}$. Sulfamic acid (EM Science) removes $\mathrm{NO}_{2}$ gases from the off-gas stream so they do

Experimental Set-Up

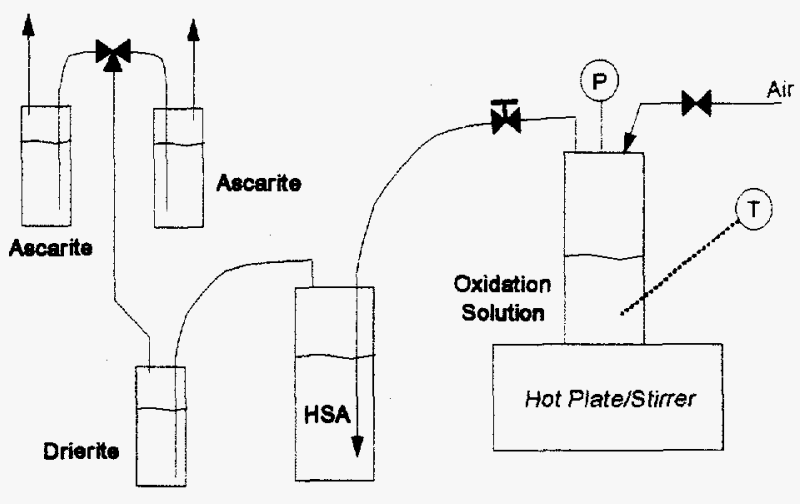

Figure 1 not absorb on the ascarite. Drierite (W. A. Hammond Drierite Co.) absorbs moisture from the gas stream. Polyethylene samples were taken from Nalgene ${ }^{\circledR}$ bottles. Trimsol ${ }^{\circledR}$ was provided by Master Chemical Company.

\section{Oxidation of Different Compounds:}

As discussed earlier, oxygenated compounds are more easily decomposed than aliphatic compounds, requiring one $\mathrm{NO}_{2}$ to cleave a bond instead of three. This is clearly depicted in Figure 2 which shows the oxidation, under different conditions, of the primary compounds in the target feed stream (each sample contained comparable levels of carbon). The difference between PVC and polyethylene stems from different dissolution characteristics. Polyethylene dissolves faster than PVC and, therefore, experiences faster reaction rates due to the increased surface 
areas of its dissolved state. The nearly constant oxidation rate of PVC may be attributed to its slow dissolution.

Parametric Studies with Water-Soluble Oil: As is evident from Figure 2 and the fact that plastics account for about 400,000 of the 1 million pounds of solid TRU waste, the rate-limiting step in the process is oxidation of plastics. Because of this, a brief parametric study was run with a water-soluble oil

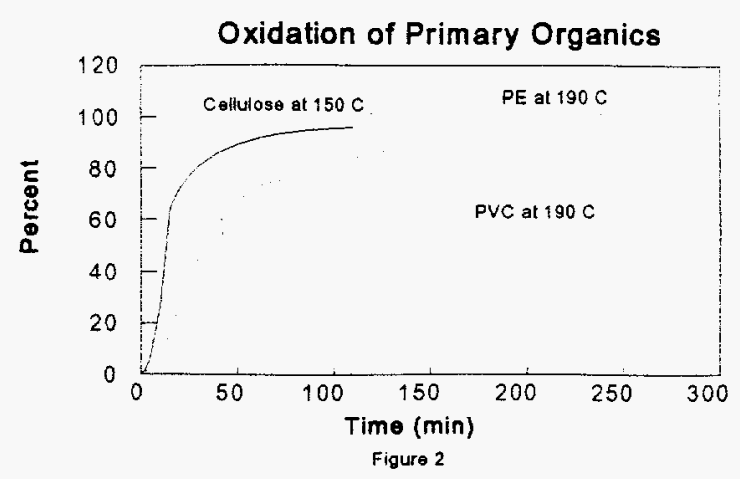
(Trimsol) to better understand the effects of temperature, acid concentration, and organic concentration.. Trimsol simulates the plastics once they dissolve; it is also the same oil used in machining throughout the DOE Complex, particularly Rocky Flats.

Although it is known that reaction rate increases with both temperature and acid concentration, these experiments quantify those effects. Figure 3 shows the importance of temperature.

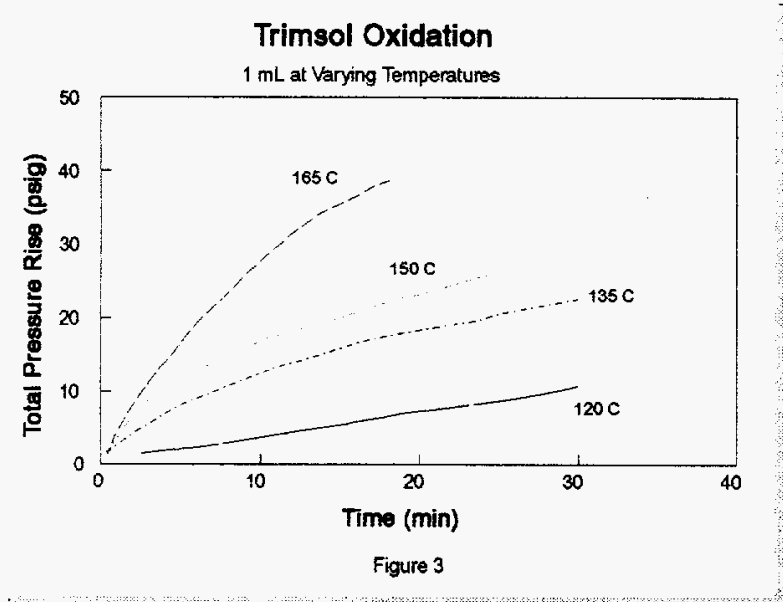

Calcualted oxidation rates for runs at 120,135 , 150 , and $165^{\circ} \mathrm{C}$, respectively, are $0.7,1.8,3.3$, and $5.5 \mathrm{~mL} /($ hrliter of solution). It is interesting that the data suggests that the reactions at 120,135 , and $150^{\circ} \mathrm{C}$ probably do not go to completion, which is in general agreement with what was reported by Seminov. ${ }^{1}$ Figure 4 depicts the role of nitric acid concentration at $165^{\circ} \mathrm{C}$. The corresponding oxidation rates for $0.1,0.5$, and $1.0 \mathrm{M}$ nitric acid are $1.4,5.0$, and 5.7 $\mathrm{mL} /$ (hrliter of solution). Figure 5 shows oxidations at varying oil concentrations. Based on Figure 5, it has been estimated that the optimum oil concentration in this system would occur at $12-14 \mathrm{~mL}$, or $2 \%$ by volume. Under these conditions, the corresponding oxidation rate is estimated at $26 \mathrm{~mL} /(\mathrm{hr}$ liter of solution). It is not yet clear how the data of Figure 5 correlates with other dissolved organic compounds, but is expected to be conservative because the aliphatic nature of the oil tends to be difficult to oxidize.

A subsequent test was run to determine which parameter plays a greater role, temperature or acid concentration. In this experiment, starting solutions were made at 155,170 , and $185^{\circ} \mathrm{C}$ which had the maximum soluble nitric acid

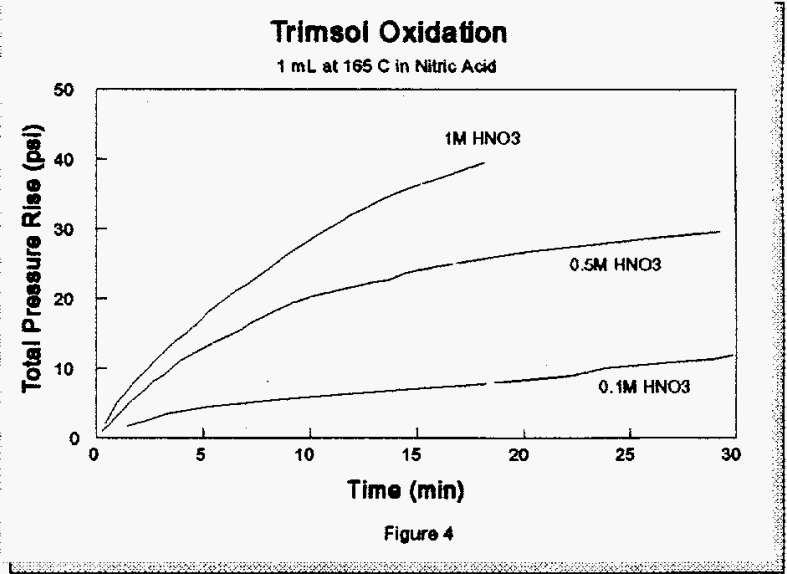



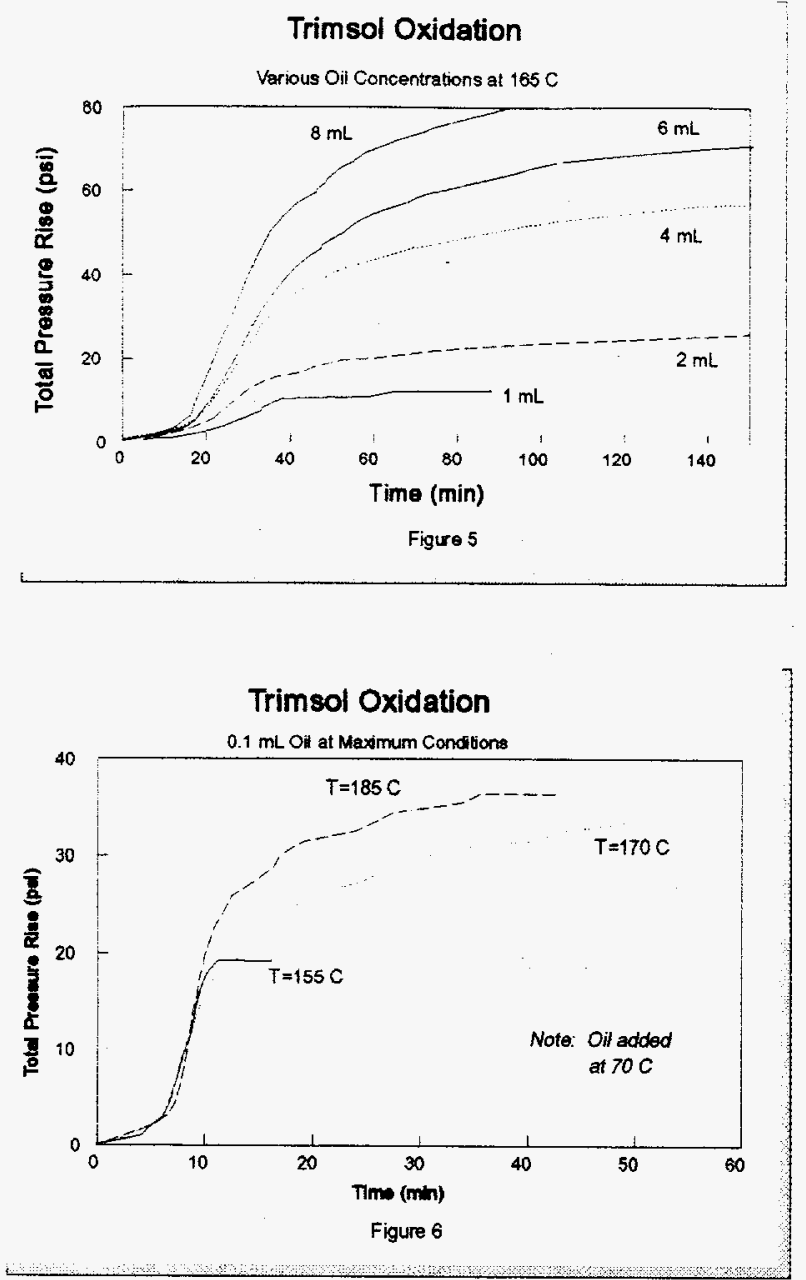

concentration; solubility is a function of temperature. The respective nitric acid concentrations in concentrated phosphoric acid were $0.148,0.0645$, and $0.0195 \mathrm{~g} / \mathrm{mL}$. The data has been plotted in Figure 6. The initial oxidation rate for each of these is about 35 $\mathrm{mL} /($ hrliter of solution).

The results were unexpected as each temperature exhibited essentially the same initial reaction rate. However, the oxidation characteristics of more stable compounds is apparent as the reaction at $155^{\circ} \mathrm{C}$ stops before completion and the reaction at $170^{\circ} \mathrm{C}$ achieves complete oxidation at a much slower rate than $185^{\circ} \mathrm{C}$. The slowing of the reaction at $185^{\circ} \mathrm{C}$ may also be a function of acid depletion, but this has not been determined experimentally.

Based on this experiment, it is believed that optimum conditions for easily-oxidized compounds (cellulose) involve lower temperatures and higher acid concentrations due to rapid reactions and corresponding rapid acid depletion. Optimum conditions for plastics use elevated temperatures where the oxidation of long-chain intermediates is more important. The value of using elevated

pressures to obtain both higher temperatures and acid concentrations will be discussed in the next section.

\section{Oxidation of Plastics:}

The earliest experiments in the oxidation of plastics used sealed vessels and microwave heating. This approach was taken because microwave vessels offered high pressure capabilities, and it was expected that microwaves might play a role in the oxidation. Making precise statements based on the early tests is difficult due to the inability to monitor temperature or pressure. Nonetheless, experiments run using microwaves provided insight into the effects of nitric acid concentration on polyethylene dissolution (Table 4). This set of data reflects quite well what was shown in Figure 5 using Trimsol. A later microwave test during a vendor demonstration

\begin{tabular}{|c|c|c|c|}
\hline $\begin{array}{l}\text { HNOS Molarity } \\
\text { in Conc. H3PO4 }\end{array}$ & $\operatorname{Tim}_{(\min )}$ & $\begin{array}{l}\text { Liquid Volume } \\
\text { (mL) }\end{array}$ & × Digested \\
\hline 1.0 & 45 & 7.5 & 87.5 \\
\hline 0.5 & 45 & 7.5 & 50.7 \\
\hline 0.2 & 45 & 7.5 & 17.4 \\
\hline 0.1 & 45 & 7.5 & 0 \\
\hline 1.0 & 45 & 15 & 100 \\
\hline 0.5 & 45 & 15 & 82.3 \\
\hline 1.0 & 55 & 15 & 100 \\
\hline 0.5 & 55 & 15 & 88.7 \\
\hline
\end{tabular}


suggests that the temperature for the tests represented in Table 4 was approximately $150-160^{\circ} \mathrm{C}$ and 15 psig.

In later experiments, when equipment was built in which oxidation could be observed, a better understanding of the effects of microwaves was obtained. The first tests ran with only acid in the digestion vessel and with temperature monitoring at the liquid surface and at the center of the liquid. When this was done, it was observed that surface temperatures were sometimes $20-30^{\circ} \mathrm{C}$ higher; this is because microwaves are absorbed at the liquid surface. A follow-up test observed the response of a plastic sample that was both submerged and sticking out of solution. This test showed reaction to be slow for the submerged portion and much faster at the surface; some sample bubbling was seen just above the liquid surface. Based on this data, it is suspected that microwaves affect oxidation in two ways. First, they provide a higher surface temperature for reaction while the bulk solution temperature is lower. Second, microwave may actually interact with and heat partially-reacted plastics which are not normally susceptible to microwave energy absorption; this increases temperatures and reaction rates at the plastic surface. More work is still needed in this area, and microwaves may still play a valuable role.

The results observed with microwaves fostered tests using conventional heating to oxidize polyethylene. Runs at two different temperatures, $0-5 \mathrm{psig}$, and the maximum soluble concentration of nitric acid yielded the results of Figure 7. Once again, as was observed with Trimsol in Figure 6, the initial reaction rates are almost identical. It was also observed that the test at the higher temperature showed better oxidation of the more-stable, long-chain intermediates. The temperature effect for plastics is not as pronounced as that for Trimsol because the plastic is a solid and

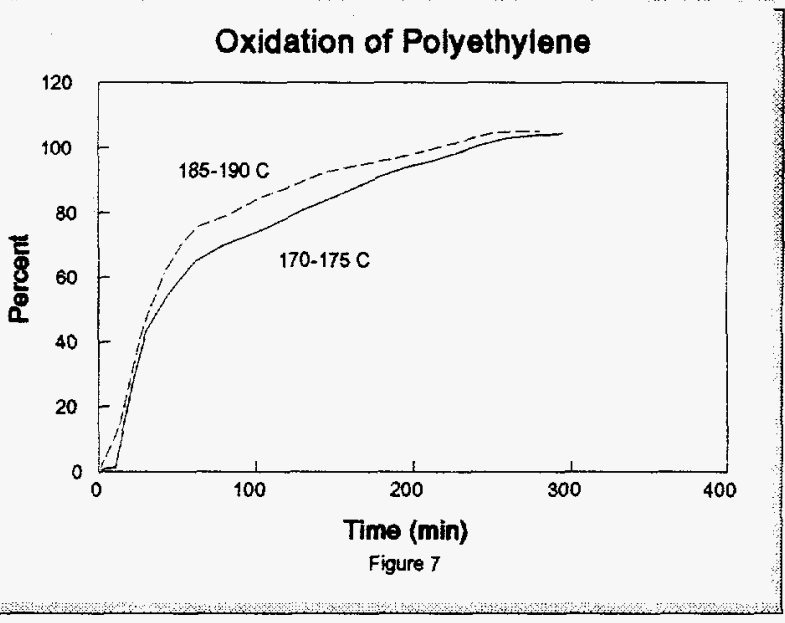
has a more limited surface area in contact with solution. Tests using the same temperature and acid concentrations while varying the pressure seemed to have little effect on oxidation rates.

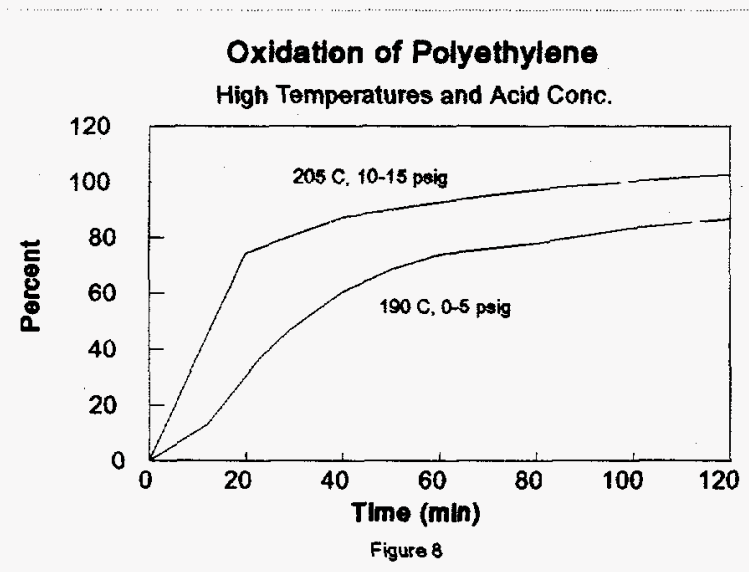

Because the parameter of pressure by itself had no observable impact on plastic oxidation, it was determined that the primary value of pressurized systems (as in the microwave) is that they permit both higher reaction temperatures and acid concentrations instead of forcing the selection one or the other. The effect of having both higher temperatures and acid concentrations is clearly shown for polyethylene in Figure 8. Calculations using the graph yield oxidation rates at 175,190 , and $205^{\circ} \mathrm{C}$ of $0.036,0.034$, and $0.107 \mathrm{~g} / \mathrm{cm}^{2} \cdot \mathrm{hr}$, respectively. 


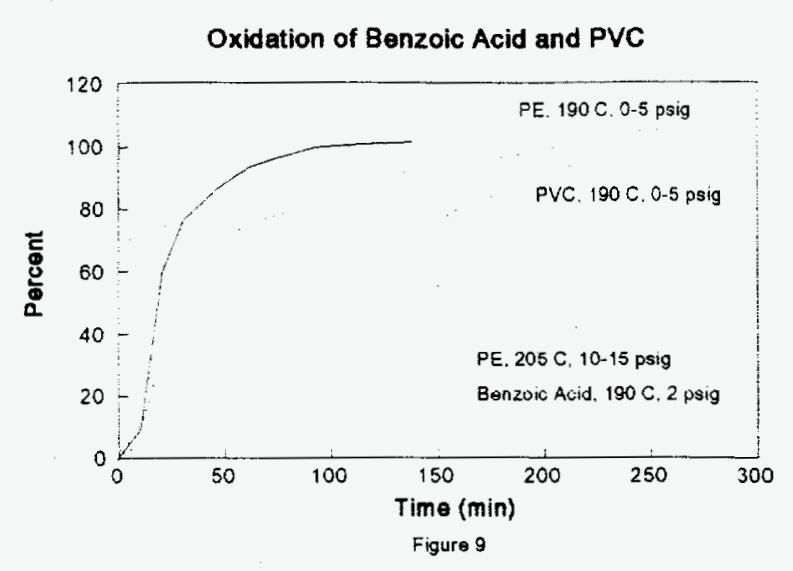

Figure 9 shows the comparative data for PVC and benzoic acid. The oxidation of benzoic acid, an aromatic compound, is sufficiently fast to not require elevated pressures; the higher oxidation rate is not surprising because the benzoic acid readily dissolves into the nitric-phosphoric acid. Oxidation rates of ion exchange resins, a component of the target waste stream which contains benzene rings, are expected to be comparable to plastics and not benzoic acid. However, the benzoic acid oxidation does demonstrate that aromatic compounds will be completely oxidized once they dissolve. Based on this data, it is clear

that the optimum system for plastics will seek a safe way to maximize temperature and nitric acid concentration using elevated pressures. However, moderate oxidation rates can still be achieved using lower temperatures and atmospheric pressure.

\section{Nitric Acid Recovery: ${ }^{8}$}

Since the oxidation process reduces nitric acid to nitrous acid and then to NO and NO gases, acid recovery will be an essential operation for maximizing chemical recycle and minimizing emissions or secondary waste streams. Some of the prominent reactions (there are many) governing acid recovery are: ${ }^{9}$

$$
\begin{gathered}
3 \mathrm{NO}_{2}<--->\mathrm{HNO}_{3}+\mathrm{H}_{2} \mathrm{O}+2 \mathrm{NO} \\
2 \mathrm{NO}+\mathrm{O}_{2}<---->2 \mathrm{NO}_{2} \\
2 \mathrm{NO}_{2}<---->\mathrm{N}_{2} \mathrm{O}_{4} \\
\mathrm{~N}_{2} \mathrm{O}_{4}+\mathrm{H}_{2} \mathrm{O}<--->\mathrm{HNO}_{2}+\mathrm{HNO}_{3} \\
2 \mathrm{HNO}_{2}+\mathrm{O}_{2}<--->2 \mathrm{HNO}_{3}
\end{gathered}
$$

Tests were run with four compounds to gain preliminary understanding into NOx generation levels for the broad range of potential feeds: cellulose (oxygenated, solid), starch (oxygenated, water-soluble), TBP (aliphatic, water-soluble), and polyethylene (aliphatic, solid). The results are shown in Table 5.

The main thing obvious from Table 5 is that oxygenated compounds generate more NOx per mole of carbon than aliphatic compounds. This is attributable to acid reabsorption. Oxygenated compounds generate more NOx because their reaction rates are much faster and permit less time for reabsorption to occur. Another observation that is significant is that polyethylene generates minimal NO gas. This can also be attributed to reaction rates because NO, the decomposition product of $\mathrm{HNO}_{2}$, is given more time to recombine with oxygen to form $\mathrm{NO}_{2}$. The same is also true for TBP, but not as prevalent because TBP oxidizes much faster than polyethylene. A third noteworthy observation is that the two water-soluble compounds exhibited a $\mathrm{NO}_{2}: \mathrm{NO}$ ratio of about 2; however, this may just be coincidence. These conclusion are only preliminary 
observations, and the gas generation characteristics require additional study, particularly as a function of temperature and oxidation rate.

The importance of this set of data is it shows that fostering nitric acid recombination in the oxidation vessel can significantly reduce the size of acid recovery unit needed. Design calculations conducted prior to these experiments projected NOx generation to be 2 moles per mole of carbon for polyethylene, the primary waste component.

Table 5 Acid Recovery Preliminary Results (NOx Generation/Mole C)

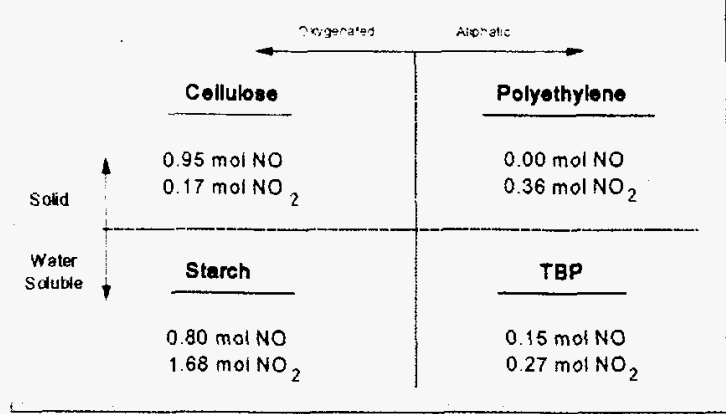
Revised calculations place the gas generation rate closer to 0.5 moles of NOx per mole of carbon, a four-fold reduction.

\section{Decontamination Effects:}

The principle behind these tests is that literature states that hot phosphoric acid is excellent at dissolving plutonium oxide. Consequently, it is expected that this chemistry can be extended to the removal of surface contamination from noncombustible solids while the oxidation of combustible materials occurs. Coupons of five different materials were tested; the materials tested include glass, carbon steel, Plexiglas ${ }^{\circledR}$, hard rubber, and soft rubber. Where applicable, samples contains rough and smooth surfaces where contamination may collect which cannot be removed using mechanical scrubbing.

All samples produced promising results. Each sample was prepared by contacting it with a $\mathrm{Pu}$-bearing solution. The samples were then surveyed to determine the levels of smearable and fixed contamination. Next, they were soaked in $0.1 \mathrm{M}$ nitric acid for 3 hours and cleaned by hand with a decontamination chemical; this

Table 6. Phosphoric Adid Deconentamination Effects (aiphahotagamma)

\begin{tabular}{|c|c|c|c|}
\hline Semple & $\begin{array}{l}\text { Intitial } \\
\text { Conteniretion }\end{array}$ & $\begin{array}{c}\text { Fored } \\
\text { Contamination }\end{array}$ & $\begin{array}{c}\text { Fina } \\
\text { Conterintion }\end{array}$ \\
\hline glass (s) & 1E5/ & 1E4/5E4 & nd/nd \\
\hline glass (r) & 7E5'- & 2E4/5E4 & ndtind \\
\hline Plexiglas (s) & 2E55E5 & FE4/5E4 & 1000 ind \\
\hline Pexiglas (r) & 6E58E5 & 价 $15 E 4$ & 3000 ind \\
\hline Hd. Rb (s) & $>1 E A>8 E 5$ & $>1 E Q>\& E 5$ & $3000 / 1500$ \\
\hline Hat Ro (r) & $>1 E G>B E 5$ & $>1 E \alpha>8 E 5$ & $3000 / 1500$ \\
\hline Solt Rubber & $>1 E G>B E 5$ & TE58E5 & 4000 ind \\
\hline Sted & $>1 E A>B E 5$ & $>1 E Q>8 E 5$ & 1000 ind \\
\hline
\end{tabular}

having to oxidize them while materials that oxidize easily (rubber and paper) can be completely removed most or all of the smearable contamination. Last, the samples were placed individually in hot nitric-phosphoric acid for 5 minutes and then an additional 10 minutes; the soft rubber and Plexiglas ${ }^{\circledR}$ were returned to the acid for an additional 45 minutes while the glass sample spent only the original five minutes in solution. Surveying of the samples yielded the results in Table 6 for alpha/beta-gamma contamination ( $\mathrm{nd}=$ none detected).

The results with the glass and steel are most significant because they are noncombustible and will not be completely oxidized by the solution. Additionally, difficult to oxidize materials (such as plastics) may be decontaminated without 
oxidized. This opens new possibilities for treating this waste without having to completely oxidize all of the combustibles.

\section{Materials of Construction:}

The fact that nitric-phosphoric acid attacks stable organic materials at elevated temperatures makes it likely that it will also aggressively corrode many metals too. Earlier corrosion data, mentioned earlier, and information in the literature on the corrosivity of phosphoric acid provided hope that high-alloy stainless steels would be satisfactory for construction of main processing equipment. In an attempt to identify suitable materials of construction, scoping tests were run with seven candidate metals in nitricphosphoric acid at $150-160^{\circ} \mathrm{C}$ : the materials used were $304 \mathrm{~L}, 316 \mathrm{~L}, 317 \mathrm{~L}$, and Alloy-20 stainless steels, C-22 and C-276 Hastelloys, and tantalum (Table 7).

Data on vapor phase corrosion showed that $317 \mathrm{~L}$ SS and Hastelloy C-22 are good candidates for the acid recovery system. Of the

Table 7. Scoping Study Corrosion Rates Seven-day Corrosion Test

\begin{tabular}{lccc}
\multicolumn{1}{c}{ Materlal } & $\begin{array}{c}\text { Llquld } \\
\text { Phase }\end{array}$ & $\begin{array}{c}\text { Vapor } \\
\text { Phase }\end{array}$ & $\begin{array}{c}\text { Condensate } \\
\text { Phase }\end{array}$ \\
304L Stainless & 0.44 & 0.25 & 0.09 \\
316L Stainless & 0.24 & 0.18 & 0.00 \\
317L Stainless & 0.34 & 0.008 & 0.00 \\
Alloy 20 Stainless & 0.27 & ind & 0.00 \\
& & & \\
Hastelloy C-22 & 0.21 & 0.0013 & 0.00 \\
Hastelloy C-276 & 0.44 & ind & 0.00 \\
Tantalum & & & 0.00
\end{tabular}

Note C-22 and Tantalum data from 14-day test seven materials tested, only tantalum exhibited sufficient corrosion resistance to be used as the oxidation vessel; this raises concerns regarding the cost of a digestion vessel. This, however, is not as substantial an issue as it first appears. Since the system will operate near atmospheric pressure, glass-lined and Teflon ${ }^{\mathbb{B}}$-lined vessels are also candidate materials for the oxidation vessels. The use of glass-lined and Teflon ${ }^{\circledR}$-lined vessels helps keeps the capital cost of equipment and replacements low. All other equipment which handles lower-temperature processing can be constructed from inexpensive materials such as $304 \mathrm{~L}$ or $316 \mathrm{~L}$ stainless steel or Hastelloy C-276.

\section{CONCLUSIONS}

A process exists which could greatly benefit Solid Waste Management through the complete oxidation and decontamination of their solid Pu-238 waste. Most types of organic compounds can be quantitatively decomposed in nitric-phosphoric acid below $200^{\circ} \mathrm{C}$ at atmospheric pressure. Of the main waste stream organics, cellulose oxidizes readily while polyethylene and $\mathrm{PVC}$ react at moderate rates. Increasing the system pressure to 10-15 psig greatly improves the oxidation rates of polyethylene to that of cellulose; this greatly increases process throughput. Trace amounts of palladium should be used to maintain the production of $\mathrm{CO}$ well below flammable levels.

Released $\mathrm{HNO}_{3}, \mathrm{NO}$, and $\mathrm{NO}_{2}$ can be recovered and recycled in a standard air driven acid recovery system providing a cheap source of oxidant. Acid recovery data shows that much of the NOx reabsorbs back into the phosphoric acid, thereby reducing the size of acid recovery 
system required. The process also has shown a significant capacity for decontaminating noncombustible compounds such as glass and steel, a major component of the Pu-238 waste..

The work conducted over the past few months has brought this technology a long way towards understanding what must be done to run a process on a larger scale. Based on what is known, this system is nearly ready for scale-up to a five- to ten-gallon system. The next twelve months of this program are likely to center on the following:

1. Complete small-scale testing with PVC. Almost all plastics studies have looked at polyethylene. However, what little has been done with PVC indicates that its oxidation characteristics are not analogous to those of polyethylene.

2. Investigate mechanisms for enhancing oxidation rates. We have yet to conduct any studies in this arena and this is the logical step prior to building anything for larger-scale testing.

3. Design and build a 5- or 10-gallon unit for larger-scale testing.

4. Conduct larger-scale testing on the primary components in the target feed stream (cellulose, polyethylene, and PVC). Also, begin tests on simulant feed mixture containing various organic materials to be encountered in the target feed.

5. Complete NOx generation testing and use the data to build an acid recovery unit for testing with the larger-scale unit.

6. Complete testing on the recovery of dissolved metals in solution.

7. Provide a preliminary full-scale design, flowsheet, and cost estimate.

A related area which shows promise and should be investigated is the use of partial oxidation and partial decontamination. In this approach, less severe processing condition would be used such that the noncombustibles and plastics are decontaminated while easily oxidized materials (paper and rubber) are decomposed. This would result in less-severe processing conditions and reduced system cost because decontamination takes only a few minutes whereas plastics oxidation requires two hours and system capable of maintaining 10-15 psig. The use of a partial decontamination could greatly reduce the demands placed on the system; this could lead to less-severe processing conditions and lower overall costs.

Other developments of this technology outside of the current line of testing could also prove to be very beneficial to SRS and other end users. This first development involves using the technology for destroying volatile organic compounds. This could probably be done in a packed-bed reactor with little change to the existing chemistry; volatile components are expected to oxidize quickly. The second development area entails developing an oxidation system that uses only nitric acid (the subject of a recent SRTC invention disclosure). Early studies of plastics oxidation showed dissolution of many different polymers in only nitric acid. A 
nitric-acid-only system would have to be run at elevated pressures, but offers the valuable benefits associated with recovering metals from solution using either evaporation, ion exchange, or precipitation. In addition, materials of construction requirements may be less severe.

\section{SUMMARY}

Nitric-phosphoric acid-air oxidation has been developed to address the needs of SRS Solid Waste Management. This technology aims to destroy or decontaminate over 1 million pounds of SRS Pu-238 contaminated job control waste, a heterogeneous mixture of plastics, cellulosics, rubber materials, and noncombustibles. The $\mathrm{Pu}-238$ will then be concentrated and shipped to WIPP. This process will provide at least a $99.9 \%$ volume reduction and result in an estimated cost savings of $\$ 35-50$ million in storage, packaging, and shipping costs. Since the issue of contaminated organic waste is not unique to Solid Waste Management, the goals of this program are also consistent with other issues at Savannah River, DOE facilities, DoD installations, commercial nuclear operations, hazardous waste generators in private industry, and smallvolume generators such as university and medical laboratories. Based on current data, the technology has also exhibited potential for remediating hazardous liquids and solids.

To address this broad category of waste, many different organic compounds have been quantitatively oxidized in nitric-phosphoric acid. These compounds represent a cross-section of waste that must be treated, and contain most types of chemical bonds to be encountered.

Elevating the temperature to $200^{\circ} \mathrm{C}$ and the pressure to 15 psig significantly enhances oxidation rates, particularly for plastics, resins, and solid aromatic compounds. The use of even higher temperatures and pressures could eliminate the need to use a phosphoric acid medium, but is currently perceived as undesirable because of the impact on scale-up and safety.

Tests have shown that acid recovery requirements will be lower than expected, as much as $75 \%$ lower. Other experiments have shown the technology to have exceptional decontaminating capabilities for noncombustible materials. Preliminary precipitation data indicates that small amounts of metals in the feed (as in mixed-hazardous wastes) should be removable with little impact on operation; cases for larger quantities require more study.

The process is nearly ready for testing with larger-scale equipment (5-10 gallons) using organic feeds with little or no metals. Prior to scale-up, some development should be conducted on methods to enhance oxidation rates. Additional developments in the areas of volatile organic compounds and mixed aqueous-organic streams, although not applicable to Solid Waste Management, could prove to be beneficial to SRS as well as other generators of hazardous or contaminated organic materials and become a significant source of technology transfer initiatives. 


\section{REFERENCES}

1. Seminov, N.N., Some Problems in Chemical Kinetics and Reactivity, Princeton Univ. Press, Vol. 1 and 2, 1958.

2. Dickerson, R.E., Molecular Thermodynamics, the Benjamin/CummingsPubl. Co., 1969.

3. Smith, J.R., "Air-Nitric Acid Destructive Oxidation of Organic Wastes," WSRC-MS-93-169, Savannah River Site, Aiken, SC 29808.

4. Katz, J.J., Seaborg, G.T., and Morss, L.R. (editors), The Chemistry of the Actinide Elements, Chapman and Hall, 1986, pp. 700-701.

5. Cleveland, J.M., The Chemistry of Plutonium, American Nuclear Society, 1979, p 438.

6. Schweitzer, P.A. (editor), Corrosion Resistance Tables, 3rd Edition, Marcel Dekker, Inc., 1991.

7. Smith, J. R., Pierce, R. A., and Sturcken, E. F., "Nitric-Phosphoric Acid Treatment of TRU Wastes," WSRC-RP-93-1304.

8. Poprik, D. C., Laboratory Notebook, WSRC-NB-94-0192, Issue 6-27-94.

9. Counce, R. M., et. al., "Performance Models for NOx Absorbers/Strippers," Environmental Progress, 1990 (Vol. 9, No. 2), pp. 77-92. 


\section{Attachment 1: Compounds Oxidized}

$\underset{\text { EOTA }}{\mathrm{HOOCH}_{2} \mathrm{CH}_{2} \mathrm{C}} \mathrm{N}^{-\mathrm{C}^{-} \mathrm{C}^{-} \mathrm{N}} \underset{\mathrm{CH}_{2} \mathrm{COOH}}{\mathrm{CH}_{2} \mathrm{COOH}}$

$\mathrm{H} \mathrm{OH}$

$\mathrm{HOOC}-\mathrm{C}-\mathrm{C}-\mathrm{COOH}$

$\mathrm{HOH}$

Tartaric Acid<smiles>O=C(O)c1ccccc1</smiles>

Benzoic Acid

\author{
$\mathrm{CH}_{3} \mathrm{NO}_{2}$
}

Nitromethane

\section{$\mathrm{P}\left(\mathrm{CH}_{2} \mathrm{CH}_{2} \mathrm{CH}_{2} \mathrm{CH}_{3}\right)$ \\ Tributylphosphate}

$\left(\mathrm{CH}_{2}\right)_{n}$

Polyethylene

$\left(\mathrm{CH}_{2} \mathrm{CHCl}\right)_{n}$

Polyvinylchloride

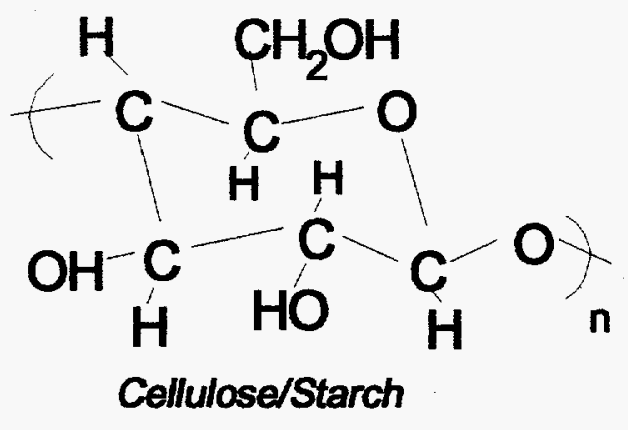

$(\mathrm{CH}=\mathrm{CCl}-\mathrm{CH}=\mathrm{CH})_{n}$ Neoprene 